\title{
Long-distance dispersal helps germinating mahogany seedlings escape defoliation by a specialist caterpillar
}

\author{
Julian M. Norghauer · James Grogan · Jay R. Malcolm • \\ Jeanine M. Felfili
}

Received: 27 April 2009 / Accepted: 28 September 2009 / Published online: 3 November 2009

(C) Springer-Verlag 2009

\begin{abstract}
Herbivores and pathogens with acute host specificity may promote high tree diversity in tropical forests by causing distance- and density-dependent mortality of seedlings, but evidence is scarce. Although Lepidoptera larvae are the most abundant and host-specific guild of herbivores in these forests, their impact upon seedling distributions remains largely unknown. A firm test of the mechanism underpinning the Janzen-Connell hypothesis is difficult, even for a single tree species, because it requires more than just manipulating seeds and seedlings and recording their fates. Experimental tests require: (1) an insect herbivore that is identified and highly specialised, (2) linkage to an in situ measure (or prevention) of herbivory,
\end{abstract}

Communicated by Jacqui Shykoff.

J. M. Norghauer · J. R. Malcolm

Faculty of Forestry, University of Toronto,

Earth Sciences Building, 33 Willcocks Street,

Toronto, ON M5S 3B3, Canada

J. R. Malcolm

e-mail: jay.malcolm@utoronto.ca

J. Grogan

Yale University School of Forestry and Environmental Studies, 360 Prospect Street, New Haven, CT 06511, USA

e-mail: jgrogan@ crocker.com

J. M. Felfili

Departamento de Engenharia Florestal, Universidade de Brasília, CP 04357, Brasília, DF 70919-970, Brazil

e-mail: felfili@unb.br

Present Address:

J. M. Norghauer $(\bowtie)$

Institute of Plant Sciences, University of Bern,

21 Altenbergrain, 3013 Bern, Switzerland

e-mail: julian.norghauer@ips.unibe.ch;

jules.norghauer@utoronto.ca and (3) evaluation and confirmation among many conspecific adult trees across years. Here we present experimental evidence for a spatially explicit interaction between newly germinating seedlings of a Neotropical emergent tree, bigleaf mahogany (Swietenia macrophylla, Meliaceae), and caterpillars of a noctuid moth (Steniscadia poliophaea). In the understory of a southeastern Amazon forest, the proportion of attacks, leaf area lost, and seedling mortality due to this specialised herbivore peaked near Swietenia trees, but declined significantly with increasing distance from mature fruiting trees, as predicted by the Janzen-Connell hypothesis. We conclude that long-distance dispersal events $(>50 \mathrm{~m})$ provided an early survival advantage for Swietenia seedlings, and propose that the role of larval Lepidoptera as JanzenConnell vectors may be underappreciated in tropical forests.

Keywords Janzen-Connell hypothesis .

Plant-insect interactions · Seedling herbivory ·

Swietenia macrophylla $\cdot$ Tropical forest

\section{Introduction}

Up to several hundred tree species can inhabit a single hectare of primary forest in the tropics (Richards 1996; Turner 2001). Several ecological processes—not one alone-likely enable so many species to co-exist (reviewed by Wright 2002), but these are likely to vary in their relative importance within and across different forests. Natural enemies of plants are thought to play an important role in maintaining this extraordinary diversity by disproportionately attacking young conspecific trees where they are aggregated, thereby freeing up space and resources for other tree species (Janzen 1970; Connell 1971; the Janzen-Connell hypothesis). Because most seeds land beneath the parent 
tree, long-distance seed dispersal by wind or animals may help some propagules become locally rare enough to evade lethal attacks from herbivores or pathogens (Ridley 1930). Although there is ample evidence of increased recruitment away from conspecific trees, far less attention has been paid to its causes (reviewed by Carson et al. 2008).

Negative density dependence in tree growth and mortality rates is a spatially explicit process that has received increasing support from large, pan-tropical forest dynamics plots (reviewed by Zimmerman et al. 2008). This support, however, is largely limited to individuals $>1 \mathrm{~cm}$ diameter, and thus overlooks the smallest stem classes, which are the most abundant and vulnerable to death (but see Webb and Peart 1999; Harms et al. 2000). Although consistent with the Janzen-Connell hypothesis, these studies do not directly test its underlying mechanism because suspected biotic agents have not been identified and their specific roles in reducing recruitment have not been elucidated. Moreover, how strongly herbivores and pathogens exert a diversity-promoting effect via intraspecific density-dependent mortality rests heavily on two key life history characteristics: having a very narrow diet breadth, and being common in forests (reviewed by Freckleton and Lewis 2006; Carson et al. 2008).

The most abundant herbivores in tropical forests are larvae of butterflies and moths (Lepidoptera), the majority of which feed upon one or a few closely related tree species within a genus (Janzen 1981, 1988; Barone 1998; Novotny et al. 2002, 2004; Dyer et al. 2007). By virtue of their abundance and relatively high degree of host specialisation, one might expect caterpillars to strongly influence seedling and sapling distribution patterns, especially during the vital seed-to-seedling stage of development when trees are succulent, abundant and most vulnerable to death (Ridley 1930; Richards 1996; Turner 2001). And yet, to our knowledge, no caterpillar has been shown to attack and kill newly germinated seedlings close to parent trees in natural forests in the context of the Janzen-Connell hypothesis.

In this study we experimentally tested the prediction that new seedlings emerging from seeds farther from mature trees are more likely to escape lethal attack by a caterpillar than seedlings establishing closer to parent trees. In the state of Pará, Brazil the wind-dispersed canopy-emergent tree big-leaf mahogany, Swietenia macrophylla King (Meliaceae), is the only known host plant of a tiny pale grey moth, Steniscadia poliophaea Hampson (Noctuidae: Sarrothripinae). The moth's larval instars feed on expanding meristematic tissues-new leaves, leaf rachi, and stemsof mahogany seedlings and small saplings and appear to be absent in crowns of Swietenia adult trees (Grogan 2001; Norghauer et al. 2006a, 2008). This research was prompted by preliminary studies indicating higher seedling recruitment rates far from fruiting Swietenia trees, a pattern whose cause was unknown but was speculated to be the result of S. poliophaea herbivory (Grogan and Galvão 2006a; Norghauer et al. 2006b).

\section{Materials and methods}

\section{Study species}

Mahogany seeds are relatively large (mean $=0.35 \mathrm{~g}$ dry weight), winged, and wind dispersed in the dry season. In southeast Pará, dry season winds blow most seeds westnorthwest of parent trees, with median dispersal distances of $28 \mathrm{~m}$ and $9 \mathrm{~m}$ on west and east sides of trees, respectively. Nearly $100 \%$ of seeds fall within $100 \mathrm{~m}$ in an area of 0.91 ha surrounding the parent tree, though extreme longdistance dispersal beyond $350 \mathrm{~m}$ has been observed (Grogan and Galvão 2006a). Seeds have no long-term dormancy mechanisms (Lamb 1966), with moisture availability associated with the onset of the rainy season during October-November triggering germination (Morris et al. 2000). Newly established seedlings are $15-20 \mathrm{~cm}$ tall with two pairs of simple leaves (Fig. 1a). After initial leaves mature, established seedlings typically flush leaves after 2-3 months depending on light conditions. Seedlings can resprout after breakage or extensive defoliation, though understory light levels are too low to power a full recovery.

First instar Steniscadia poliophaea emerge from tiny disc-shaped eggs (1-2 mm diameter) laid on the underside of expanding initial seedling leaves. The pale yellow caterpillars feed voraciously for 5-10 days, causing characteristic patterns of leaf damage (Fig. 1a,b). Each instar phase turns deeper yellow; the final instar is ca. $2 \mathrm{~cm}$ in length and sports a halo of fine hairs (Fig. 1d). S. poliophaea caterpillars preferentially feed on immature mahogany leaves; they have not been observed on other tree species under natural conditions nor do they accept meristematic tissues from other species under controlled conditions. After caterpillars pupate, adult moths emerge from the cocoons after 10-11 days. The entire egg-to-moth transformation requires 18-22 days (Grogan 2001).

It is important to distinguish $S$. poliophaea from the better-known Hypsipyla grandella and Hypsipyla robusta shoot-boring caterpillars that attack large saplings and poles of Swietenia and other juvenile Meliaceae trees across the tropics (Mayhew and Newton 1998; Nair 2007). While $H$. grandella is undoubtedly a pervasive pest in Neotropical plantations, to the best of our knowledge its distance- and/or density-dependent effect on Swietenia growth and mortality in natural populations has not been reported [but see Sullivan (2003) for the tree Tabebuia ochracea (Bignoniaceae)]. The forestry literature regarding $H$. grandella is largely anecdotal and focused on plantation 
Fig. 1 Photos showing: a intact, recently established Swietenia macrophylla seedling; b late-instar caterpillar (Steniscadia poliophaea, ca. $1.5-2.0 \mathrm{~cm}$ long) feeding on a newly germinating seedling; c recently established seedling that survived a caterpillar attack (note the characteristic webbing, frass, and residual damage on mature leaves); d late-instar caterpillar eating stem tissue on a $100 \%$ defoliated seedling. Photos by J. M. N. from the study site in Pará, Brazil
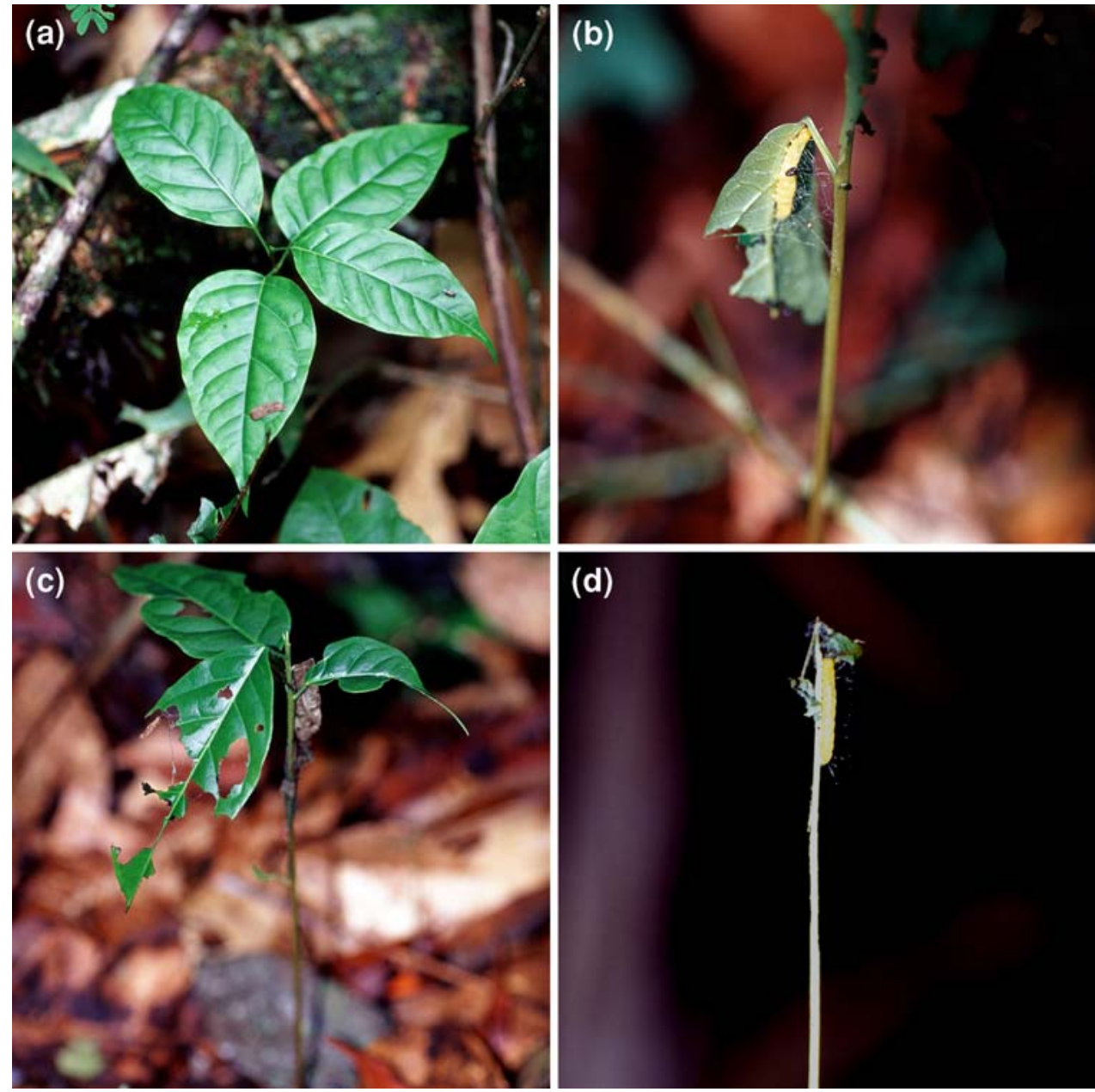

settings (e.g. Mayhew and Newton 1998) that are very different from species-rich primary and secondary forests (Nair 2007).

\section{Study site}

We conducted our study in the Kayapó Indigenous Territory, Pará, Brazil, where an 8,000-ha reserve (hereafter referred to as "Pinkaitî") protects a natural population of Swietenia macrophylla trees (Swietenia hereon). This forest is semi-evergreen, unlogged, and experiences relatively little hunting pressure. Yearly rainfall can vary from 1,500 to $2,100 \mathrm{~mm}$, concentrated in September-May with virtually no rainfall during the dry season months (June-August; Grogan and Galvão 2006b).

\section{Seed sowing}

We maintained a fixed seed density $\left(5\right.$ seeds $\left.\mathrm{m}^{-2}\right)$ in our experimental plots. This density is representative of natural seed densities observed on the ground beneath tree crowns during typical fruiting years. While low compared to seed densities occasionally observed beneath heavily fruiting individual trees or clusters of trees (up to $30 \mathrm{~m}^{-2}$ ), this fixed density is high compared to natural seed densities observed beyond tree crown perimeters. We chose this density for use at all mature "parent" trees selected for study because seed production is unpredictable, being highly variable within and among reproductive adults $[>20-30 \mathrm{~cm}$ diameter at breast height (DBH)] across years (Snook et al. 2005; Grogan and Galvão 2006a).

In mid August 2003, seven large fruiting Swietenia trees that were at least $200-\mathrm{m}$ upwind and $100-\mathrm{m}$ downwind from the nearest Swietenia adult were selected as sites for seed plots. Nearest-neighbour distances among the seven trees averaged $732 \mathrm{~m}$ (range: $250-1800 \mathrm{~m}$ ). These trees were a small subset of a much larger, comprehensive 3-year Janzen-Connell experimental study (J. M. Norghauer et al., in preparation), and were selected to not only maximise interspersion but also to span the natural variation seen in both adult size and fruit crop at the study site (mean $\mathrm{DBH} \pm 1 \mathrm{SD}: 104.3 \mathrm{~cm} \pm 19.1 \mathrm{~cm}$, range $=67.0-128.1 \mathrm{~cm})$. Freshly fallen Swietenia seeds were collected under a cluster of three large fruiting trees not included in the study 1 
month before outplanting, screened for viability, and well mixed.

We established six $2-\mathrm{m} \times 2-\mathrm{m}$ plots per tree along a $100-\mathrm{m}$ transect that ran downwind of each Swietenia tree. Plots were located at 5, 15, 30, 50, 75 and $100 \mathrm{~m}$ from each tree, though distances were occasionally adjusted to avoid major canopy openings, and marked with $0.5-\mathrm{m}$-tall wire stake flags for relocation. In each plot 20 seeds were dropped from a height of $0.5 \mathrm{~m}$ into an X-shaped array, corresponding to a density of 5 seeds $\mathrm{m}^{-2}$. Average percent canopy openness above the seed plots $(n=42)$, measured in four cardinal directions per plot using a handheld spherical densitometer, was $1.9 \% \pm 1.17 \mathrm{SD}$.

We gauged the pre-existing (or "background") density of natural seedfall by counting naturally dispersed seeds in each experimental plot just prior to sowing. This likely underestimated actual background seed densities at scales larger than the $2-\mathrm{m} \times 2-\mathrm{m}$ plot because those eaten whole by larger vertebrates would have been missed. Both intact seeds and those predated by mammals and/or insects (papery wing left or visible holes in the seed hull, respectively) were counted. To prevent confusion with experimental seeds we removed any naturally fallen seeds from the plots and tossed them 1-2 $\mathrm{m}$ away in a haphazard direction. Over a 6-week period from mid October through late November 2003, as detailed below, we scored plots for seed predation, monitored them for seed germination and seedling attack, and then measured the extent of herbivory by $S$. poliophaea caterpillars.

\section{Measuring seed predation}

Small vertebrates prey on Swietenia macrophylla seeds in the study region, either by removing the whole seed or more often by partly consuming the propagule, leaving discernible teeth marks on the diaspore hull that once encased the missing seed embryo (Grogan and Galvão 2006a; Norghauer et al. 2006b). Insect attacks were identified by tiny bored holes, and fungal pathogens by a softening of the seed hull but no sign of animal attack. We considered seeds whose hull or complete propagule was removed as eaten (the latter rarely happened). While using seed removal as an index of seed predation can lead to misleading results (Vander Wall et al. 2005), hoarding of Swietenia seeds is likely infrequent in the Pará region (Grogan 2001). We used regression to model the effect of distance from a mature tree on the proportion of seeds predated per plot (arcsine square root transformed).

\section{Measuring seedling herbivory and recruitment}

We measured missing leaf area to the nearest square millimetre in mid November on all nearly or fully expanded green leaves using a transparent plastic grid gently overlaid onto individual seedlings leaves (Coley 1983; Aide 1993). We first calculated an average percent damage per seedling and then derived plot-level averages for statistical analyses, as seedlings within plots could not be considered statistically independent (Quinn and Keough 2002). Percent leaf herbivory and proportions of seedlings attacked and $100 \%$ defoliated by $S$. poliophaea caterpillars were analysed using regression models in which the mature Swietenia tree was used as a random blocking factor. In subsequent models the blocking factor was removed because it was not close to significant. We checked for curve linearity in these response variables (arcsine square root transformed) by comparing least-squares linear and quadratic regressions. Little evidence of curve linearity was detected for the proportion of seedlings $100 \%$ defoliated (quadratic term $F_{1,40}=0.30$, $P=0.59$ ), whereas it was almost significant for percent damage (quadratic term $F_{1,40}=2.52, P=0.12$ ) and proportion of seedlings attacked (quadratic term $F_{1,40}=3.43$, $P=0.072$ ), showing a concave downward relationship. All regression models were weighted by the plot-level counts of successful germinants. Finally, seedling recruitment was expressed on a per plot basis by counting the number of seedlings alive in May 2004, at the end of the first wet (growing) season, and then dividing by the number of: (1) pre-herbivory germinants; and (2) initial seeds added (20 per plot, 840 seeds total). All response variables were arcsine square root transformed in the reported regression models to stabilise variance and normalise residuals.

Separating distance from density effects

Dispersal distance and seed density are often inversely correlated in tree populations and thus are practically indistinguishable (Janzen 1970; Clark and Clark 1985; Richards 1996). All plots, however, shared the same experimental seed density. It remains unclear, then, whether distance from a mature tree, plot seedling density per se, and/or neighbourhood density was the main factor to which $S$. poliophaea females were responding to, resulting in more attacks and pervasive defoliation near Swietenia trees. In three separate multiple linear regression models (using type III sum of squares), distance to mature tree, plot density of pre-herbivory germinants, and neighbourhood density of natural seedfall (log-transformed) were used as independent variables. The response variables were arcsine square root transformed: (1) mean percent damage, (2) proportion of seedlings attacked, and (3) proportion of seedlings $100 \%$ defoliated by S. poliophaea caterpillars. Tolerance values were used to check the degree of independence between predictors. In all three models, the values for each predictor ranged from 0.55 to 0.90 and were judged acceptable (i.e. >0.10; Quinn and Keough 2002). 
All statistical analyses were conducted using SAS version 8.2 (SAS Institute, Cary, N.C.). Other multiple regression assumptions were checked using graphics of residuals, histograms, and quantile plots.

\section{Results}

Seed predation by small mammals did not appear to vary according to distance from a mature Swietenia tree and was highly variable across plots, ranging from 0 to $95 \%$, but least variable beneath tree crowns (Fig. 2a). Overall, less than $1 \%$ of propagules were removed entirely (i.e. diaspore including papery wing), with an additional $4.1 \%$ destroyed by boring insects and pathogens (34 of 840 seeds). This predation plus 14 cases of failed or aborted germination reduced the density of pre-herbivory successful germinants,
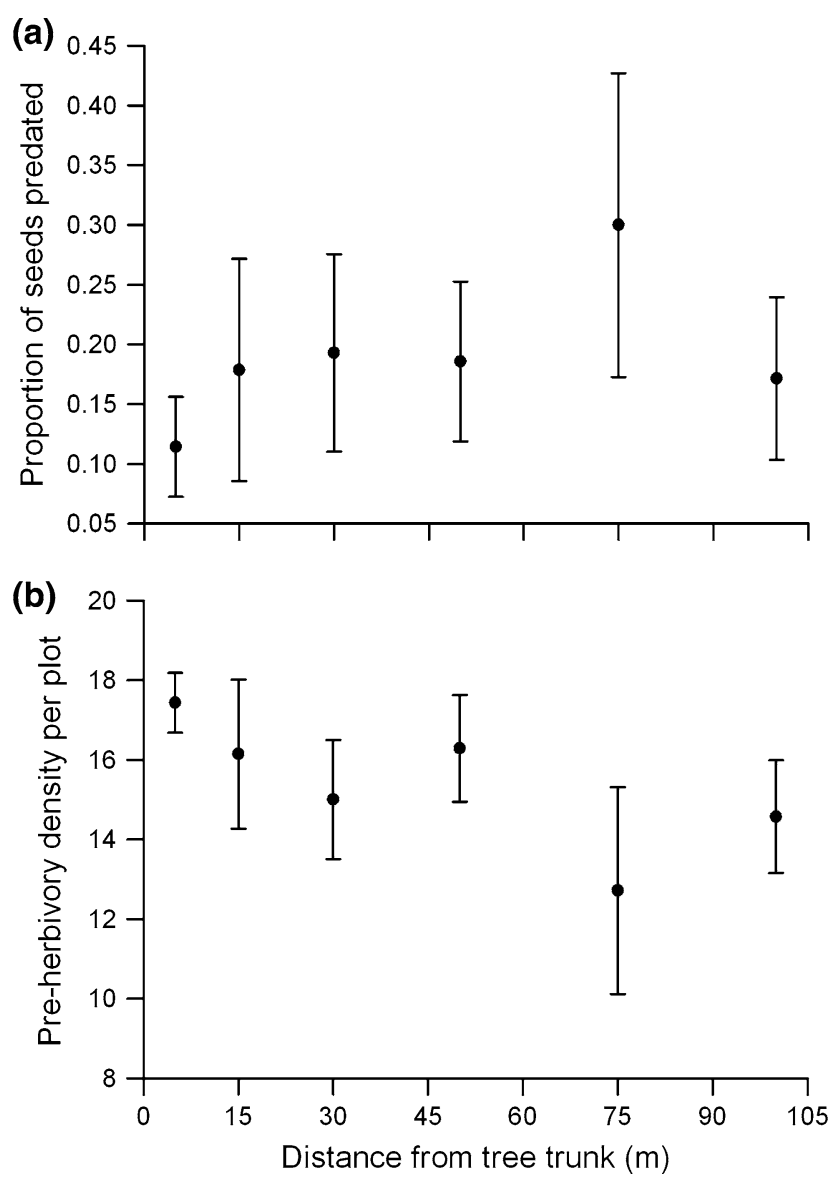

Fig. 2 Relationship between distance from a mature fruiting tree $(n=7)$ and the post-dispersal fates of Swietenia macrophylla seeds at the Pinkaití forest reserve in Pará, Brazil. a The proportion of seeds predated by vertebrates (non-weighted linear regression, $F_{1,41}=0.98$, $r^{2}=0.024, P=0.33$ ). b The number of pre-herbivory seedlings (i.e. those seeds that escaped predation and successfully germinated) per plot (Kruskal-Wallis test, $d f=5, \chi^{2}=4.56, P=0.47$ ). Shown are means \pm $1 \mathrm{SE}$ on average, by one-quarter (from 20 seeds to 15.4 germinants, $n=42$ plots), resulting in a non-significant decrease in germinants with distance from a mature tree (Fig. 2b).

In stark contrast to seed predation, the proportion of emerging seedlings attacked by the specialist herbivore, $S$. poliophaea, peaked within $15 \mathrm{~m}$ of mature Swietenia trees, but declined to near zero at 75-m and 100-m distances (Fig. 3a). The average amount of leaf area lost to S. poliophaea caterpillars approached $60 \%$ within $15 \mathrm{~m}$ of trees, but dropped to near zero at the furthest distances from a mature tree (Fig. 3a). Cases of $100 \%$ herbivory (Fig. 3b) were greatest within $15 \mathrm{~m}$ of trees, where nearly half of all experimental seedlings were completely defoliated-and those not eaten completely were left severely damaged. Less than $6 \%$ of seedlings had their leaves damaged by an insect herbivore other than $S$. poliophaea and their percent damage was unrelated to distance from a mature tree (median $=10 \%$; Kruskal-Wallis test, $P=0.75$ ). The proportion of Swietenia seeds alive as seedlings at the end of the first growing season (i.e. seedling recruitment in May 2004) increased significantly with distance from a mature tree, as predicted by the Janzen-Connell hypothesis (Fig. 3b). Model fits improved when a single plot at a distance of $100 \mathrm{~m}$ from a mature tree that had $100 \%$ mortality was excluded from regression analyses (for germinants, $F_{1,39}=33.1, r^{2}=0.47, P<0.0001$; for seeds, $F_{1,39}=22.8$, $\left.r^{2}=0.37, P<0.0001\right)$. When data were analysed at the scale of individual seedlings, the negative effects of the caterpillar were even starker. Only $3 \%$ of attacked seedlings were alive in May 2004 whereas 43\% that escaped attack survived to the end of the wet season. Only $12 \%$ of seedlings within $50 \mathrm{~m}$ of mature trees survived, whereas $35 \%$ survived beyond $50 \mathrm{~m}\left(\chi^{2}\right.$ test, $\left.\chi^{2}=44.8, d f=1, P<0.0001\right)$.

We used multiple regression analyses to compare the explanatory powers of distance, plot seedling density, and neighbourhood seedling density. Distance from a mature Swietenia tree was the strongest predictor for the three response variables: (1) percent damage, (2) proportion escaping attack, and (3) proportion $100 \%$ defoliated by the specialist herbivore [standard partial regression coefficients for distance, $b_{(1)}{ }^{\prime}=-0.66 ; b_{(2)}{ }^{\prime}=+0.75 ; b_{(3)}{ }^{\prime}=-0.72$; for each parameter, $P<0.0001]$. By contrast, pre-herbivory seedling density within plots (at a spatial scale of $4 \mathrm{~m}^{2}$ ) was not a significant predictor for any response variable [standard partial regression coefficients for seedling density, $b_{(1)}{ }^{\prime}=+0.07, P=0.41 ; b_{(2)}{ }^{\prime}=-0.13, P=0.10$; $\left.b_{(3)}{ }^{\prime}=0.02, P=0.82\right]$. However, the $\log$ neighbourhood density of natural seedfall was a significant predictor (positive) of percent damage to Swietenia seedlings, but not a significant predictor of escape from attack or complete defoliation of seedlings [standard partial regression coefficients for background seed density, $b_{(1)}{ }^{\prime}=+0.26, \quad P=0.018$; $\left.b_{(2)}{ }^{\prime}=-0.16, P=0.091 ; b_{(3)}{ }^{\prime}=0.17, P=0.14\right]$. Overall, 

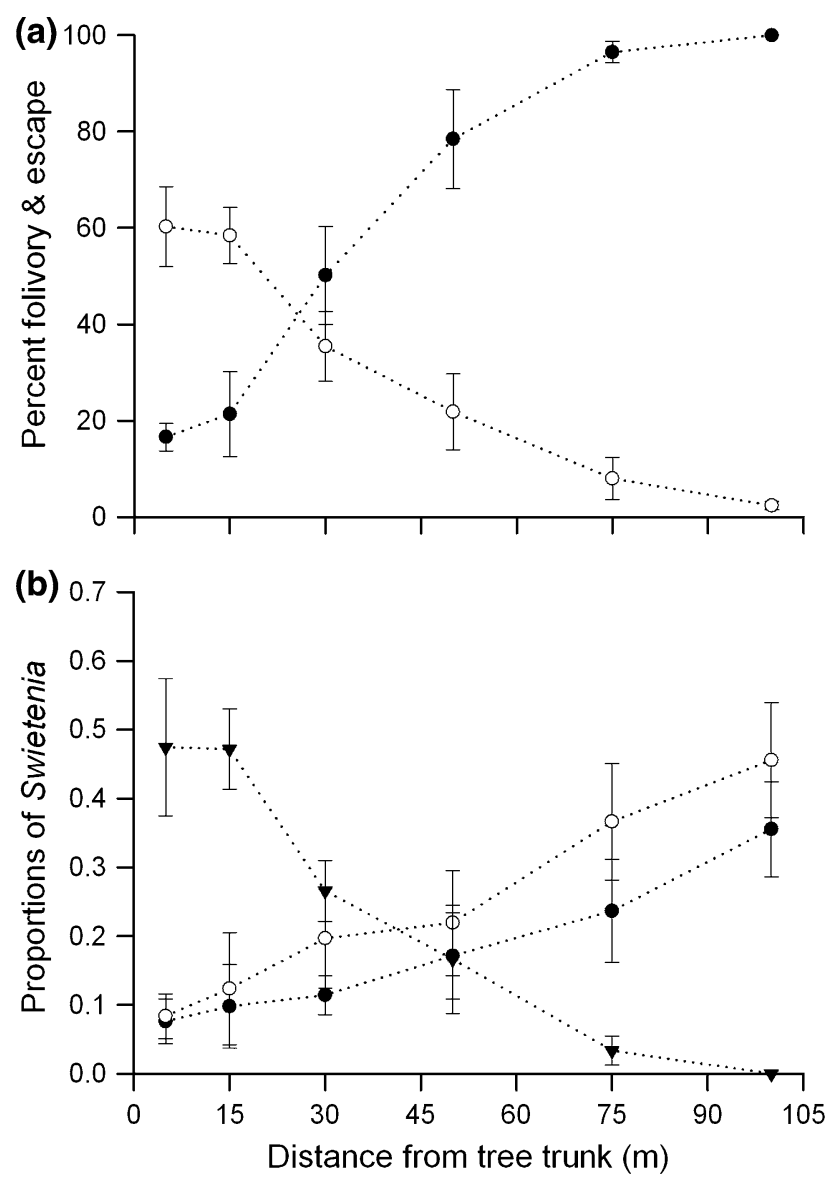

Fig. 3 Relationship between distance from a mature fruiting tree $(n=7)$ and herbivory of young Swietenia macrophylla seedlings at the Pinkaití forest reserve in Pará, Brazil. a The amount of leaf area damaged on Swietenia germinants (open circles), and the percentage of seedlings escaping attack by Steniscadia poliophaea moth caterpillars (closed circles) analysed using weighted linear regression $\left(F_{1,40}=86.5, r^{2}=0.69, P<0.0001 ; F_{1,40}=132.6, r^{2}=0.77, P<0.0001\right.$, respectively). b The proportion of newly germinating Swietenia seedlings (triangles) 100\% defoliated by Steniscadia, and seedling recruitment, expressed both as the proportion of Swietenia seeds (open circles) and germinants (closed circles) alive 8 months later. Variables were analysed using weighted least regressions for defoliation $\left(F_{1,40}=84.1, r^{2}=0.68, P<0.0001\right)$ and recruitment from germinants $\left(F_{1,40}=26.2, r^{2}=0.40, P<0.0001\right)$ and non-weighted regression for recruitment from seeds sown $\left(F_{1,40}=14.4, r^{2}=0.27, P=0.0005\right)$

each model accounted for at least $70 \%$ of the variation in the three response variables [for (1) $F_{1,40}=34.6, R^{2}=0.74$; for (2) $F_{1,40}=46.2, R^{2}=0.79 ;$ and for $\left.(3) F_{1,40}=29.5, R^{2}=0.70\right]$.

\section{Discussion}

This experiment demonstrated for the first time that a specialist caterpillar (Steniscadia poliophaea) can severely defoliate new tree seedlings near conspecific mature trees (Swietenia macrophylla) and that seedlings established further downwind from adults $(>50 \mathrm{~m})$ experienced higher recruitment at the end of the first growing season. The key factor explaining these results was severe damage induced by $S$. poliophaea. This is consistent with field evidence elsewhere that specialist herbivores can cause greater leaf damage than generalists on young tropical saplings (Barone 1998). Damage to Swietenia seedlings from other insects was negligible, suggesting its expanding leaves were either toxic or unattractive to other invertebrates and vertebrates (Mayhew and Newton 1998).

Ecological processes that drive young seedling mortality can potentially have a major impact upon tree regeneration patterns in tropical forests by influencing subsequent juvenile and adult abundances and distributions (Clark and Clark 1985; Harms et al. 2000; Bell et al. 2006), which collectively can affect community structure and species composition. The Janzen-Connell hypothesis posits a conspecific spacing mechanism driven by natural enemies that hastens host mortality rates where tree densities are greatest-typically near parent trees but also where trees are clustered (Janzen 1970; Schupp 1992). However, for the Janzen-Connell mechanism to encourage high species diversity, four key conditions must apply: (1) these enemies must be species-specific or facultative (sensu Janzen 1970); (2) they must be common; (3) they must be not only distance and/or density responsive in their attack, but also capable of reducing growth and/or survival rates; and (4) the first three conditions must hold for many tree species in a forest. The present experiment is among the first to satisfy conditions (1), (2), and (3), albeit for a single tree species at one forest site.

Although many studies have documented negative effects of insect herbivores on seedlings, surprisingly few have done so in the context of the Janzen-Connell mechanism in tropical forests (Clark and Clark 1985; Blundell and Peart 1998; Massey et al. 2006). These found evidence for species-specific increases in leaf damage with either proximity to parent trees and/or immediate seedling density, but the insect herbivores implicated were not known, nor was their degree of host specialisation. So few published studies may truly reflect little investigation, but we cannot discount the possibility that many non-significant results may have gone unpublished (i.e. the "file-drawer effect"). We believe, however, that seedling herbivory by insects is less studied compared to vertebrate herbivory in Janzen-Connell tests because the effects of the former are often cryptic and harder to quantify in tropical forests.

Whilst pathogen-induced mortality during seedling establishment (i.e. die-back or damping off) has received support and recently regained attention (Augspurger 1984; Bell et al. 2006; reviewed by Freckleton and Lewis 2006), insects that eat germinating stem and leaf tissue in the seed-to-seedling phase are a group of enemies either too laborious or too ephemeral to properly study (Blundell and 
Peart 1998; Massey et al. 2006). We suspect that the fleeting seed-to-seedling phase-less than 2-3 weeks for Swietenia - coupled with a dearth of natural history knowledge in the tropics, has made it more difficult to detect the potential impact of larval Lepidoptera. Indeed, despite their ubiquity and dominance, caterpillars are rarely mentioned as either limiting establishment or shaping seedling distributions in natural forests, whereas their role as pests in tropical nurseries and of juveniles in plantations is well known, especially for young Meliaceae trees (Nair 2007).

Our results support theoretical work suggesting that vertebrates are unlikely to function as distance-responsive predators of tree seeds and seedlings (Nathan and Casagrandi 2004) but that specialised insects herbivores can (MullerLandau et al. 2003). Predation of Swietenia seeds did not vary significantly with distance from mature trees, consistent with previous investigations (Grogan and Galvão 2006a; Norghauer et al. 2006b). The increase in seedling recruitment at greater distances from mature Swietenia trees was driven primarily by $S$. poliophaea herbivory. Even partial damage to initial leaves can severely weaken seedlings and increase their risk of mortality in the lightlimited understory, where lost tissue is not easily replaced (Turner 2001; Kitajima 2003). In a Panamanian forest, Clark and Clark (1985) observed that as little as $14 \%$ of lost leaf area of initial leaves of Dipteryx panamensis decreased seedling longevity. Decreased persistence in the shaded understory for Swietenia seedlings will decrease their probability of being in or near a newly formed canopy gap-a crucial event for successful recruitment to maturity by this light-demanding species (Grogan et al. 2005). Our collective experience since 1995 indicates that the plant-caterpillar interaction described here is an annual event and that Steniscadia poliophaea's impact on Swietenia regeneration may continue beyond the first growing season, on both shaded seedlings but especially on vigorously growing seedlings and saplings near adults (Grogan 2001; Norghauer et al. 2006a, 2008).

Although we present evidence for distance responsive attacks and associated mortality from this caterpillar enemy, we did not exclude the herbivore from seedlings in order to conclusively demonstrate its impact on seedling mortality and spatial distribution [condition (2) above]. Further manipulation-ideally by removing caterpillars by hand to avoid affecting non-targeted plants, or by using insecticide or mesh netting to protect seedlings- - both near and far from isolated Swietenia adults is needed to confirm this interpretation of our results. Another caveat to our study is that fungal pathogens, falling debris, and/or trampling by animals may have increased mortality through the wet season months. For example, one experimental plot at a distance of $100 \mathrm{~m}$ lacked any seedling survivors, likely because of fungalinduced mortality from rotting fruit seen within the plot.
How was Steniscadia poliophaea able to locate these small seedlings within the narrow window of time associated with widespread seed germination, if they did not originate from Swietenia tree canopies? Because early instars of S. poliophaea larvae cannot chew mature leaves their fitness greatly depends upon speedy and efficient host location and timing of oviposition by females (Bernays 2001). They could do this by searching for Swietenia seedlings among species-rich vegetation in the forest by first using adult Swietenia trees as cues for local host abundance, perhaps via adult-generated olfactory plumes (Schoovern et al. 2005, p. 149), and then pursuing a fine-scale search in the vicinity of these adults. Our partial regressions suggest this may have occurred, in that the density of either background seeds or pre-herbivory germinants was less important than distance to the seven Swietenia adults for predicting herbivory on seedlings.

We anticipate that the spatially explicit seedling-herbivore interaction observed here is not unique to Swietenia and may apply to other tropical tree species. Young leaves of tropical tree seedlings and saplings are loaded with anti-herbivore chemical defences and yet still incur high rates of leaf damage irrespective of their successional status and/or shade tolerance (Coley 1983; Coley and Barone 1996). This apparent paradox - of highly toxic leaves being eaten to a greater degree than less toxic but tougher mature leaves-suggests that most consumers of young expanding tree foliage are well adapted and specialised in their diet (Cates 1980; Schoovern et al. 2005), with the prime candidates being Lepidoptera larvae (Barone 1998; Kursar et al. 2006) which are likely to be more specialised in the tropics than in temperate zones (Coley and Barone 1996; Dyer et al. 2007). We conclude that moth caterpillars may represent an underappreciated Janzen-Connell vector in natural forests and thus deserve further attention by ecologists and foresters alike.

Acknowledgments We thank the Brazilian government and the Kayapó community of A'ukre for research permission, as well as Conservation International-Brazil for logistical support in the field. We are grateful for early helpful discussions with A. A. Agrawal, S. C. Thomas, S. Smith and C. Nock; and to J. Solorzano-Filho for formatting the photos in Fig. 1. Funding was kindly provided by a doctoral scholarship to J. M. N. from Le Fonds Québécois de la Recherche sur la Nature et Technologies (Government of Québec, Canada), a grant from the Donner Foundation Canada, and a grant to J. R. M. from the Natural Sciences and Engineering Research Council of Canada. Research was done in accordance with the laws of Brazil.

\section{References}

Aide TM (1993) Patterns of leaf development and herbivory in a tropical understory community. Ecology 74:455-466

Augspurger CK (1984) Seedling survival of tropical tree species-interactions of dispersal distance, light-gaps and pathogens. Ecology 65:1705-1712

Barone JA (1998) Host-specificity of folivorous insects in a moist tropical forest. J Anim Ecol 67:400-409 
Bell T, Freckleton RP, Lewis OT (2006) Plant pathogens drive density-dependent seedling mortality in a tropical tree. Ecol Lett 9:569-574

Bernays EA (2001) Neural limitations of phytophagous insects: implications for diet breadth and affiliation. Annu Rev Entomol 46:703-727

Blundell AG, Peart DR (1998) Distance-dependence in herbivory and foliar condition for juvenile Shorea trees in Bornean dipterocarp rain forest. Oecologia 117:151-160

Carson WP, Anderson JT, Leigh EG, Schnitzer SA (2008) Challenges associated with testing and falsifying the Janzen-Connell hypothesis: a review and critique. In: Carson WP, Schnitzer SA (eds) Tropical Forest Community Ecology. Wiley-Blackwell, Oxford, pp 210-241

Cates RG (1980) Feeding patterns of monophagous, oligophagous, and polyphagous insect herbivores: the effect of resource abundance and plant chemistry. Oecologia 46:22-31

Clark DB, Clark DA (1985) Seedling dynamics of a tropical tree: impacts of herbivory and meristem damage. Ecology 66:1884-1892

Coley PD (1983) Herbivory and defensive characteristics of tree species in a lowland tropical forest. Ecol Monogr 53:209-233

Coley PD, Barone JA (1996) Herbivory and plant defenses in tropical forests. Annu Rev Ecol Syst 27:305-335

Connell JH (1971) On the role of natural enemies in preventing competitive exclusion in some marine animals and in rain forest trees. In: Den Boer PJ, Gradwell G (eds) Dynamics of populations. Centre for Agricultural Publication and Documentation, Wageningen, pp 298-312

Dyer LA, Singer MS, Lill TJ, Stireman JO, Gentry GL, Marquis RJ, Ricklefs RE, Greeney HF, Wagner DL, Morais HC, Diniz IR, Kursar TA, Coley PD (2007) Host-specificity of Lepidoptera in tropical and temperate forests. Nature 448:696-700

Freckleton RP, Lewis OT (2006) Pathogens, density-dependence and the coexistence of tropical trees. Proc R Soc B 273:29092916

Grogan JE (2001) Bigleaf mahogany (Swietenia macrophylla King) in southeast Pará, Brazil: a life history study with management guidelines for sustained production from natural forests. PhD thesis, Yale University, New Haven

Grogan J, Galvão J (2006a) Factors limiting post-logging seedling regeneration by big-leaf mahogany (Swietenia macrophylla) in southeastern Amazonia, Brazil, and implications for sustainable management. Biotropica 38:219-228

Grogan J, Galvão J (2006b) Physiographic and floristic gradients across topography in transitional seasonally dry evergreen forests of southeast Pará, Brazil. Acta Amazon 36:483-496

Grogan J, Landis RM, Ashton MS, Galvão J (2005) Growth response by big-leaf mahogany (Swietenia macrophylla) advance seedling regeneration to overhead canopy release in southeast Pará Brazil. For Ecol Manage 204:399-412

Harms KE, Wright SJ, Calderon O, Hernandez A, Herre EA (2000) Pervasive density-dependent recruitment enhances seedling diversity in a tropical forest. Nature 404:493-495

Janzen DH (1970) Herbivores and the number of tree species in tropical forests. Am Nat 104:501-528

Janzen DH (1981) Pattern of herbivory in a tropical deciduous forest. Biotropica 13:271-282

Janzen DH (1988) Ecological characterization of a Costa Rican dry forest caterpillar fauna. Biotropica 20:120-135

Kitajima K (2003) Impact of cotyledon and leaf removal on seedling survival in three tree species with contrasting cotyledon functions. Biotropica 35:429-434

Kursar TA, Wolfe BT, Epps MJ, Coley PD (2006) Food quality, competition and parasitism influence feeding preference in a neotropical lepidopteran. Ecology 87:3058-3069
Lamb FB (1966) Mahogany of tropical America: its ecology and management. University of Michigan Press, Ann Arbor

Massey FP, Massey K, Press MC, Hartley SE (2006) Neighbourhood composition determines growth, architecture and herbivory in tropical rain forest tree seedlings. J Ecol 94:646-655

Mayhew JE, Newton AC (1998) The silviculture of mahogany. CAB International, Wallingford

Morris MH, Negreros-Castillo P, Mize C (2000) Sowing date, shade and irrigation affect big-leaf mahogany (Swietenia macrophylla King). For Ecol Manage 132:173-181

Muller-Landau HC, Levin SA, Keymer JE (2003) Theoretical perspectives on evolution of long-distance dispersal and the example of specialised pests. Ecology 84:1957-1967

Nair KSS (2007) Tropical forest insect pests: ecology, impact and management. Cambridge University Press, Cambridge

Nathan R, Casagrandi R (2004) A simple mechanistic model of seed dispersal, predation and plant establishment: Janzen-Connell and beyond. J Ecol 92:733-746

Norghauer JM, Malcolm JR, Zimmerman BL (2006a) Juvenile mortality and attacks by a specialist herbivore increase with conspecific adult basal area of Amazonian Swietenia macrophylla (Meliaceae). J Trop Ecol 22:451-460

Norghauer JM, Malcolm JR, Zimmerman BL (2006b) An experimental test of density- and distant-dependent recruitment of mahogany (Swietenia macrophylla) in southeastern Amazonia. Oecologia 148:437-446

Norghauer JM, Malcolm JR, Zimmerman BL (2008) Canopy cover mediates interactions between a specialist caterpillar and seedlings of a tropical tree. J Ecol 96:103-113

Novotny V, Basset Y, Miller SE, Weiblen GD, Bremer B, Cizek L, Drozd P (2002) Low host specificity of herbivorous insects in a tropical forest. Nature 416:841-844

Novotny V, Miller SE, Leps J, Basset Y, Bitto D, Janda M, Hulcr J, Damas K, Weiblen GD (2004) No tree an island: the plant-caterpillar food web of a secondary rain forest in New Guinea. Ecol Lett 7:1090-1100

Quinn GP, Keough MJ (2002) Experimental design and data analysis for biologists. Cambridge University Press, New York

Richards PW (1996) The tropical rain forest. An ecological study, 2nd edn. Cambridge University Press, Cambridge

Ridley HN (1930) Dispersal of plants throughout the world. Reeve, Ashford

Schoovern LM, van Loon JJA, Dicke M (2005) Insect-plant biology, 2nd edn. Oxford University Press, Oxford

Schupp EW (1992) The Janzen-Connell model for tropical tree diversity - population implications and the importance of spatial scale. Am Nat 140:526-530

Snook LK, Cámara-Cabrales L, Kelty MJ (2005) Six years of fruit production by mahogany trees (Swietenia macrophylla King): patterns of variation and implications for sustainability. For Ecol Manage 206:221-235

Sullivan JJ (2003) Density-dependent shoot-borer herbivory increases the age of first reproduction and mortality of neotropical tree saplings. Oecologia 136:96-106

Turner IM (2001) The ecology of trees in the tropical rain forest. Cambridge University Press, Cambridge

Vander Wall SB, Kuhn MK, Beck MJ (2005) Seed removal, seed predation, and secondary dispersal. Ecology 86:801-806

Webb CO, Peart DR (1999) Seedling density-dependence promotes co-existence of Bornean rain forest trees. Ecology 80:2006-2017

Wright SJ (2002) Plant diversity in tropical forests: a review of mechanisms of species co-existence. Oecologia 130:1-14

Zimmerman JK, Thompson J, Brokaw N (2008) Large tropical forest dynamics plots: testing explanations for the maintenance of species diversity. In: Carson WP, Schnitzer SA (eds) Tropical forest community ecology. Wiley-Blackwell, Oxford, pp 89-117 